\title{
Stimulasi Perkembangan Motorik Halus Anak Usia Dini dalam Seni Tradisional Tatah Sungging
}

\author{
Octavian Dwi Tanto ${ }^{\varpi_{1}}$, Aulia Humaimah Sufyana ${ }^{2}$ \\ Pendidikan Anak Usia Dini, Universitas Negeri Jakarta \\ DOI: $10.31004 /$ obsesi.v4i2.421
}

\begin{abstract}
Abstrak
Seni Traditional Tatah Sungging merupakan istilahlain dari kerajinan membuat wayang kulit yang memiliki peranan penting dalam menstimulasi aspek perkembangan motorik halus anak. Melalui seni ini, koordinasi mata dan tangan anak berkembang selama dilibatkan orangtuanya untuk membuat karya yang presisi dengan mengikuti tata cara pakem penggunaan alat dan bahan tatah sungging. Kontradiktif dengan pandangan tradisional, penelitian kualitatif dengan pendekatan studi kasus ini mencoba untuk menjelaskan temuan penting mengenai terstimulasinya aspek motorik halus anak selama proses pembuatan karya tatah sungging. Hasil penelitian ini menunjukkan bahwa terampilnya anak dalam membuat karya tatah sungging mencerminkan aspek motorik halus yang terstimulasi sepanjang proses ini berlangsung. Kesimpulan dari penelitian ini mendeskripsikan bahwa tatah sungging merupakan seni tradisional yang tidak hanya memiliki nilai pelestarian budaya, namun juga memiliki nilai edukasi sebagai kegiatan yang dapat mengembangkan aspek motorik halus anak.
\end{abstract}

Kata Kunci: motorik halus; seni tradisional tatah sunggin; anak usia dini

\begin{abstract}
Traditional art of Tatah Sungging is a term of craft to make shadow puppets which has an important role in stimulating the development of fine motor children. Through this art, the child's eye and hand coordination develops as long as his parents are involved in making a precise work by following the standard procedures to use the tools and materials of tatah sungging. Contradictory to traditional views, this qualitative reseach with case study approach is trying to explain the important findings about the stimulation of children fine motor aspects during the process of making tatah sungging works. The results of this study indicate that the child's skill in making tatah sungging works reflects the fine motor aspects that are stimulated throughout this process. The conclusion of this study describe that tatah sungging is a traditional art that not only has the value of cultural preservation, but also has the value of education as an activity that can develop the fine motor aspects of children.
\end{abstract}

Keywords:fine motor development; traditional art of tatah sungging; early childhood.

Copyright (c) 2020 Octavian Dwi Tanto, Aulia Humaimah Sufyana

$\triangle$ Corresponding author:

Email Address : 14.octavian@gmail.com (Ploso, Jombang, Jawa Timur)

Received 7 January 2020, Accepted 13 January 2020, Published 14 January 2020 


\section{PENDAHULUAN}

Seni tradisional tatah sungging dimaknai oleh masyarakat Kepuhsari, Jawa Tengah sebagai simbol eksistensi kerajinan tangan dalam membuat wayang kulit(Prayoga, 2017). Setiap pola tatahan dan sunggingan pakem yang dibuat melalui kerajinan ini, mencerminkan bagaimana karakter tokoh wayang yang antagonis dan prontagonis(O. D. Tanto, 2019). Kontras dengan pandangan budaya, tatah sungging juga memiliki makna sebagai kerajinan tangan yang dapat menstimulasi perkembangan motorik halus anak. Selama proses pembuatan wayang kulit berlangsung, anak menggunakan berbagai macam alat tatah yang berdiameter kecil, bertekstur keras, dan tergolong benda tajam serta alat sungging yang terdiri dari kuas lukis dan pen nyeweng yang berujung lentur. Disamping itu, selama proses pembuatan wayang kulit ini berlangsung, anak juga melibatkan penggunaan bahan kulit perkamen yang memiliki permukaan bergerigi dan bertekstur keras. Pembuatan wayang kulit yang dilakukan dengan menggunakan alat dan bahan tersebut, mencerminkan bagaimana keterampilan motorik halus anak yang terstimulasi sepanjang proses pembuatan karya ini berlangsung.

Sejauh ini terdapat beberapa penelitian yang membahas tentang kegiatan anak dalam membuat wayang kulit melalui seni tatah sungging, namun belum terdapat penelitian yang membahas mengenai terstimulasinya aspek motorik halus anak melalui aktivitas tersebut. Contohnya penelitian Tanto, Hapidin, dan Asep yang membahas mengenai keterampilan sosial pengerajin tatah sungging cilik di Kepuhsari. Hasil penelitian tersebut menunjukkan bahwa para pengerajin tatah sungging cilik Kepuhsari memiliki keterampilan sosial seperti gotong royong, empati, dan komunikasi yang terbentuk melalui proses dorongan dan keteladanan dalam menghasilkan karya secara presisi (O. D. Tanto, Hapidin, \& Supena, 2019a). Disamping itu, dalam sumber lain ditemukan juga penelitian yang membahas mengenai penanaman karakter anak usia dini dalam kesenian tradisional tatah sungging. Hasil penelitian tersebut menyatakan bahwa terampilnya anak dalam membuat karya tatah sungging mencerminkan karakternya seperti sabar, tekun, teliti, mandiri, tanggungjawab, disiplin, dan gotong royong yang terbentuk melalui proses dorongan, tuntutan, pembiasaan, dan keteladanan untuk menghasilkan karya secara presisi (O. D. Tanto, Hapidin, \& Supena, 2019b).

Mengacu berdasarkan hasildua penelitian tersebut, terampilnya anak-anak Kepuhsari dalam membuat karya kerajinan tatah sungging, mencerminkan bagaimana keterampilan sosial serta karakternya yang muncul selama dilibatkan dalam proses pembuatan wayang kulit secara presisi. Berbeda dengan hasil penelitian sebelumnya, penelitian kualitatif dengan pendekatan studi kasus ini mencoba untuk menjelaskan temuan mengenai aspek-aspek motorik halus yang tersimulasi dibalik terampilnya anak dalam membuat wayang kulit atau yang dikenal dengan istilah kerajinan tatah sungging.

Ditinjau dari pandangan ahli, perkembangan motorik pada anak usia dini dibagi menjadi dua, yaitu perkembangan motorik kasar dan motorik halus. Perkembangan motorik kasar merupakan perkembangan aktivitas gerak yang terkoordinasi dari beberapa bagian tubuh dan menggunakan tenaga yang lebih untuk melakukanya, sedangkan perkembangan motorik halus merupakan perkembangan aktivitas gerak koordinasi yang menggunakan tenaga relatif sedikit (O. Tanto \& Kristanto, 2015). Artinya perkembangan motorik halus atau yang dikenal dengan istilah fine motor skill merupakan bagian dari perkembangan motorik yang dimaknai sebagai gerak terbatas pada anak usia dini.

Mosby's Medical Dictionarydalam "Impairment of motor skills in children with fetal alcohol spectrum disorders in remote Australia: The Lilitwan Project" menambahkan bahwa keterampilan motorik dianggap sebagai gabungan dari keterampilan motorik halus seperti ketepatan, ketangkasan, integrasi visual-motorik dan koordinasi lengan atas dan keterampilan motorik kasar termasuk gerakan tubuh umum seperti melompat, melompat, berlari, menyeimbangkan, kekuatan dan koordinasi (Lucas et al., 2016). Motorik halus merupakan keterampilan yang melibatkan ketangkasan, ketepatan, integrasi gerakan tangan 
dan kejelian, serta koordinasi lengan atas. Kontrol gerakan tangan yang terkordinasi dengan kejelian mata dibutuhkan untuk memenuhi tugas-tugas perkembangan dan motorik halus.

Lebih spesifik menurut (Abessa et al., 2016) mengungkapkan bahwa motorik halus merupakan gerak koordinasi mata-tangan dan gerak manipulasi terhadap objek-objek kecil. Pandangan ini meyakini bahwa motorik halus merupakan kemampuan mengkoordinasikan mata dan tangan dalam memanipulasi objek-objek kecil.Artinya koordinasi mata dan tangan dalam motorik halus ini terbatas pada gerakan yang dilakukan oleh jari-jemari dan pergelangan tangan.

Motorik halus dan komponen visual dalam konsep visual-motor coordination dideskripsikan sebagai kemampuan yang meliputi ketangkasan jari, pengurutan gerak, dan kecepatan serta akurasi motorik halus. Keterampilan ini ditangkap oleh berbagai tugas sensorimotor seperti melacak, mengetuk jari, dan gerakan tangan imitatif (Carlson, Rowe, \& Curby, 2013). Artinya motorik halus merupakan bagian dari kegiatan sensorimotor yang melibatkan kemampuan koordinasi mata-tangan dalam melakukan gerakan yang berurutan, tepat, cepat, imitatif, dan gerakan-gerakan sejenis melacak.

Pandangan lain datang dari Robert \& Brett yang dikutip dalam "Convergent validity of two motor skill tests used to assess school-age children" menyatakan bahwa keterampilan motorik halus merupakan kemampuan yang meliputi manipulasi tangan dan menangkap benda, serta melibatkan penggunaan otot-otot kecil tangan untuk gerakan yang terkontrol(Lane \& Brown, 2015). Kegiatan motorik halus adalah gerak terbatas yang melibatkan penggunaan otot kecil.Penggunaan otot kecil ini bertujuan untuk mengontrol berbagai macam gerak yang dimanipulasikan oleh bagian tubuh tangan.

Pernyataan Tseng \& Chow yang dikutip dalam"Motor Proficiency of the Head Start and Typically Developing Children on MABC-2"menyatakan bahwa keterampilan motorik halus sangat penting dalam menulis karena membantu anak untuk membentuk huruf dan angka secara akurat dan "hanya dapat diproduksi dengan waktu yang tepat dan kontrol kekuatan gerakan lengan, tangan, dan jari yang terkoordinasi" (Ting Liu, Michelle Hamilton, \& Sean Smith 2015). Kegiatan motorik halus melibatkan gerakan tubuh bagian tangan seperti lengan, tangan, dan jari-jemari yang saling berkoordinasi.Artinya kegiatan motorik halus merupakan gerakan tangan, lengan tangan, dan jari-jemari tangan yang saling berkoordinasi.

Keterampilan motorik halus adalah kemampuan untuk mengendalikan gerakan melalui kegiatan koordinasi sistem saraf, fibril, dan otot seperti jari dan tangan (Syafril et al., 2018). Setiap gerak motorik halus yang dilakukan oleh anak, melibatkan komponen organ dan bagian anggota tubuh yang saling berkontribusi.Tangan dan jari jemari merupakan bagian tubuh yang berkontribusi terhadap terciptanya gerak motorik halus, sedangkan otot halus atau fibril merupakan komponen organ tubuh yang mendorong jari dan tangan dalam melakukan gerakan-gerakan manipulatif.

Berdasarkan pandangan para ahli di atas dapat dikatakan bahwa motorik halus merupakan gerakan otot halus bagian tubuh tangan, lengan tangan, pergelangan tangan, dan jari-jemari yang terkordinasi dengan mata untuk memenuhi tugas-tugas perkembangan yang membutuhkan ketepatan, kepresisian, dan ketangkasan.

Sementara itu, pengertian tatah sungging adalah suatu aktivitas yang dimulai dari pembuatan pola sampai dengan penerapan warna pada pola pahatan atau tatahan tersebut sehingga menghasilkan karya seni yang indah (Rasyid, 2018). Tatah sungging merupakan perpaduan kegiatan membuat pola tatahan dan pola pewarnaan hingga menghasilkan sebuah karya seni yang indah. Artinya, karya tatah sungging merupakan karya kerajinan tangan yang dibuat melalui proses menatah dan mewarnai.

Seni traditional tatah sungging telah dikenal bangsa Indonesia sebagai seni kriya yang dimaknai agung dan berwibawa sehingga karya tatah sungging dapat dijumpai di pusat pemetintahan pada masa kerajaan - kerajaan yang berkembang di Nusantara (Marsudi, 2013). Tatah sungging merupakan bagian dari seni budaya tradisional indonesia. 
Sumber lain menyatakan bahwa seni tradisional tatah sungging diyakini sebagai simbol eksistensi budaya wayang kulit, di mana setiap pola tatahan dan sunggingan pakem yang dibuat melalui kerajinan ini, mencerminkan karakter dari penokohan wayang kulit yang dihasilkan secara presisi (O. D. Tanto et al., 2019a). Artinya tatah sungging merupakan bagian dari seni traditional Indonesia dalam membuat karya-karya wayang kulit.

Seni tatah sungging adalah karya seni kriya kulit yang menggunakan bahan baku kulit perkamen dari kulit binatang ternak dengan teknik ditatah dan disungging untuk mewujudkan suatu karya (Marsudi, 2013). Proses kerajinan tatah sungging menghasilkan produk-produk seni yang terbuat dari kulit binatang. Lebih spesifik, Ristanti melalui jurnal yang berjudul "Potensi UMKM wayang kulit di Desa Sonorejo Kecamatan Sukoharjo Kabupaten Sukoharjo" menambahkan bahwa tatah sungging merupakan sebuah teknik menatah kulit dengan pola-pola yang rumit yang dilakukan secara terus menerus sehingga menghasilkan sebuah tatahan rapi dan indah untuk dipandang, dilanjutkan dengan teknik menyungging yang merupakan teknik mewarnai dari satu pola-pola tersebut sehingga kelengkapan pola dan keindahan serta keunikannya semakin menarik (A. I. Santoso, 2015). Tatah sungging merupakan seni yang diawali dengan proses menatah kulit, kemudian diakhiri dengan proses menyungging atau mewarnai kulit hasil tatahan.

Berdasarkan padangan di atas, dapat dimaknai bahwa tatah sunggin merupakan bagian dari seni budaya tradisional Indonesia dalam membuat wayang kulit yang diawali dengan proses penatahan pola dan diakhiri dengan proses penyunggingan atau pewarnaan kulit hasil tatahan.

\section{METODOLOGI}

Penelitian ini menggunakan metodelogi penelitian kualitatif dengan pendekatan studi kasus. Penggunaan metode ini dilakukan dengan tujuan untuk memperoleh gambaran yang kompleks dan mendalam mengenai fokus penelitian yaitu stimulasi perkembangan motorik halus anak usia dini dalam seni tradisional tatah sungging.

Lebih lanjut data-data yang diperoleh dari penelitian ini diambil menggunakan teknik pengumpulan data wawancara, observasi, dan dokumentasi. Keseluruhan data dari penelitian ini diambil dari subjek penelitian yaitu anak-anak usia 0-8 tahun di wilayah Kepuhsari yang terampil dalam membuat karya-karya tatah sungging seperti gantungan kunci, pembatas buku, kipas, hingga karya wayang kulit.

Sementara itu, teknik analisis data yang digunakan dalam penelitian ini adalah teknik analisis data Miles \& Huberman.Secara teknis, teknik analisis data ini mencakup tiga alur kegiatan yang dilakukan secara bersamaan yaitu; reduksi data, penyajian data, dan verifikasi data. Secara sederhana teknik analisis data tersebut dijelaskan melalui gambar di bawah ini;

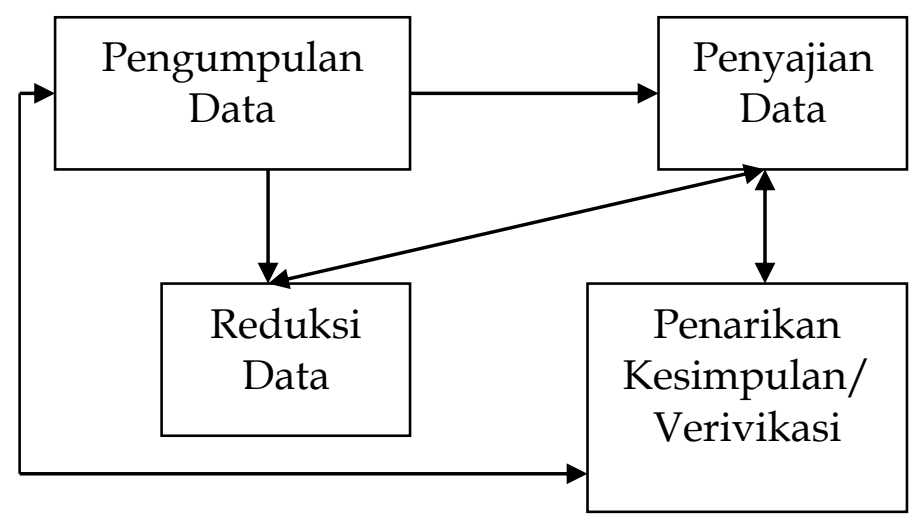

Bagan 1. Model InteraksiAnalisis Miles \& Huberman (Sugiyono, 2014) 
Tahap pengumpulan data adalah tahap mengumpulkan data-data lapangan yang dilakukan dengan menggunakan teknik observasi, wawancara, dan dokumentasi. Tahap reduksi data adalah tahap merefleksikan, memilah, dan mengelompokkan data yang sesuai dengan fokus serta sub fokus penelitian. Tahap penyajian data adalah tahap memberikan uraian singkat, bagan temuan, hubungan antar kategori, flowchart, dan sejenisnya ke dalam bentuk narasi hasil temuan penelitian. Tahap penarikan kesimpulan atau verifikasi data adalah tahap memberikan gambaran mengenai tema spesifik yang mencerminkan makna inti dari temuan penelitian.

\section{HASIL DAN PEMBAHASAN}

Berdasarkan hasil pengamatan lapangan ditemukan bahwa terdapat motorik halus anak yang terstimulasi selama melakukan pembuatan karya-karya kerajinan tatah sungging secara presisi seperti gantungan kunci, pembatas buku, kipas, wayang kulit, dan lain sebagainya. Aspek-aspek motorik halus anak yang meliputi ketepatan, kepresisian, dan ketangkasan dari gerakan otot halus bagian tubuh tangan, lengan tangan, pergelangan tangan, dan jari-jemari yang terkordinasi dengan mata, terstimulasi sepanjang anak melakukan tahapan dalam membuat karya seni tatah sungging. Terstimulasinya aspekaspek tersebut dapat dilihat dari hasil karya anak seperti gantungan kunci, pembatas buku, kipas, hingga wayang kulit yang dihasilkan secara presisi dengan menggunakan alat dan bahan tatah sungging.

Secara umum temuan ini sebagaimana tercatat dalam penelitian(Farsani, Mortazavi, Bahrami, Kalantary, \& Bizhaem, 2017) yang menyatakan bahwa salah satu manfaat dari kegiatan seni adalah dapat mengembangkan keterampilan motorik halus anak.Mendukung temuan tersebut, sumber lain menyatakan bahwa terampilnya motorik halus anak tercermin dari hasil karya lukisan yang baik dan indah (Handayani Sri, Zuhairi, 2019). Adapun (Lin, Meng, Yu, Chen, \& Li, 2014) menambahkan bahwa Contextual Fine Motor Questionnaire (CFMQ) dapat dikembangkan melalui dan mencakup 5 subskala kegiatan yaitu; mengontrol pena, penggunaan alat selama aktivitas kerajinan, penggunaan peralatan makan, mengkancingkan dan melepas kancing pakaian, dan membuka botol.

Selanjutnya, sepanjang membuat karya tatah sungging, anak berusaha untuk memanipulasi serta mengkoordinasikan gerakan tangan, pergelangan tangan, jari-jemari, dan mata untuk menghasilkan karya secara presisi dengan menggunakan alat pengeblak, penatah, dan penyungging. Setiap gerak manipulasi serta terkoordinasi tersebut dilakukan anak dengan tata cara atau aturan pakem tertentu yang harus dipatuhi pertahapannya. Secara spesifik hal ini dapat dilihat disetiap tahapan proses pembuatan karya tatah sungging mulai dari mengeblak, menatah, hingga menyungging.

Mengeblak merupakan tahap pertama dalam seni tatah sungging yang dilakukan dengan cara menjiplak gambar secara presisi pada media kulit dengan menggunakan alat tatah tratasan.Pada tahap ini, terstimulasinya aspek motorik halus dapat dilihat selama anak menjiplak sketsa karya tatah sungging secara presisi di atas permukaan kasar kulit menggunakan alat tatah tratasan yang berdiameter kecil, tergolong benda tajam, dan licin.Karaktersitik alat tatah tratasan yang berdiameter kecil, tergolong benda tajam, dan licin tersebut, mendorong jari-jemari anak lentur dan cekat dalam mengapit bagian batang alat sepanjang ujung runcingnya menggores permukaan kasar kulit secara presisi.Selain itu, karakteristik bahan kulit yang memiliki tekstur kasar mendorong jari-jemari, pergelangan tangan, serta lengan tangan anak luwes dalam menggerakkan tratasan sepanjang ujung runcingnya menggores permukaan kasar media tersebut secara presisi. Hasil blak-blaan atau jiplaan gambar gantungan kunci, pembatas buku, kipas, hingga wayang kulit yang presisi menunjukkan bahwa melalui kegiatan ini ketepatan, kepresisian, dan ketangkasan motorik halus anak terstimulasiselama proses ngeblak berlangsung. 
Temuan ini sebagaimana hasil penelitian (Putri \& Raharjo, 2020) yang menyatakan bahwa aktivitas motorik halus anak mencakup beberapa kegiatan menjiplak seperti menjiplak bentuk geometris, menjiplak jari-jemari, dan menyalin daun.Disamping, itu dalam sumber yang sama juga dijelaskan bahwa kemampuan anak dalam memegang pensil dan membuat tiruan gambar dipengaruhi oleh perkembangan motorik halusnya (Putri \& Raharjo, 2020). Adapun sumber lain mengatakan bahwa berdasarkan hasil expert reviews mengenai motorik halus anak ditemukan bahwa keterlibatan tekstur yang nyata sangat penting untuk mengoptimalkan aspek perkembangan tersebut. Hal ini dilakukan agar anak dapat merasakan kegiatan eksplorasi sekaligus dapat memperoleh pengalaman yang natural dari gerakan-gerakan yang dilakukannya (Razali, Aziz, Rasli, Zulkefly, \& Azmi, 2019).

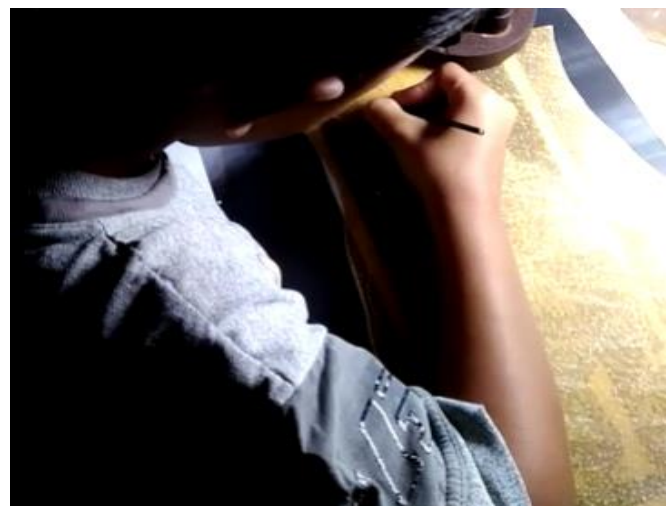

Gambar 1. Anak Mengeblak Wayang Kulit

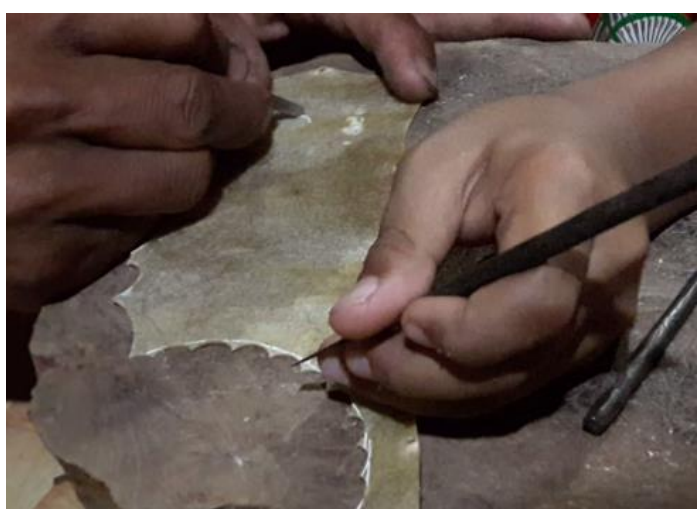

Gambar 2. Alat Tatah Tratasan yang digunakan Anak untuk Mengeblak

Selain itu, temuan di atas juga menunjukkan bahwa penggunaan alat dan bahan mengeblak yang memiliki tekstur kasar, keras, dan halus memiliki kontribusi terhadap terstimulasinya aspek motorik halus anak. Hal ini sebagaimana pandangan (Duff \& Wolff, 2018) yang menyatakan bahwa kontrol antisipatif terhadap penggunaan suatu objek mengacu pada kemampuan untuk merencanakan pergerakan atau meningkatkan kekuatan sebelum tindakan dengan mempertimbangkan ukuran, bentuk, berat, dan tekstur ketika melakukan gerakan tangan dan menilai kekuatan ujung jari yang akan digunakan untuk tindakan yang dimaksud.Hasil penelitian lain menambahkan bahwa melalui intervensi permainan rakyat anak usia dini dapatmeningkatkan keseluruan keterampilan motorik halus yang tercermin dari kemampuannya dalam menjepit, menyentuh, menggambar, dan memotong (Wei, 2016).

Disamping itu, pada tahap ini terstimulasinya aspek motorik halus anak juga dapat dilihat selama anak mengungkal tratasan tumpul menggunakan batu ungkal yang bertekstur keras, licin, dan berair.Karakteristik alat tatah tratasan yang berdiameter kecil, tergolong benda tajam, dan licin tersebut, mendorong jari-jemari anak lentur dan cekat dalam mengapit bagian batang alat selama ujung pipihnya menggesek tepat disepanjang cukungan batu ungkal yang keras, licin, dan berair.Selain itu, karaktersitik pengungkal yang bertekstur keras, licin, dan berair mendorong jari-jemari, pergelangan tangan, serta lengan tangan anak luwes dalam mengasahkan alat tatah tratasan selama ujung pipihnya menggesek tepat disepanjang cekungan batu ungkal. Hasil ungkalan yang memiliki ketajaman merata di bagian ujung runcing tratasan, menunjukkan bahwa melalui kegiatan ini ketepatan, kepresisian, dan ketangkasan motorik halus anak terstimulasi selama proses ngungkal berlangsung.

Kegiatan mengungkal pada tahap mengeblak yang menstimulasi aspek motorik halus ini dilakukan ketika alat tratasan yang digunakan anak tumpul.Terstimulasinya aspek motorik halus ini dapat dilihat sepanjang anak mengungkal tratasan yang tumpul menggunakan batu ungkal hingga memperoleh ketajaman merata dibagian sisi pipih dari ujung runcingnya.Temuan tersebut sebagaimana hasil penelitian (Geuze et al., 2012) yang 
menyatakan bahwa untuk mengukur kecepatan, kekuatan, dan akurasi kemampuan tangan salah satunya dapat dilakukan dengan kegiatan meruncingkan tongkat menggunakan pisau. Lebih spesifik sumber lain juga menegaskan bahwa meraut pensil merupakan salah satu bagian dari beberapa kegiatan yang mencerminkan kreativitas anak dibidang motorik halus (Susanto, 2011).

Selanjutnya, menatah merupakan tahap kedua dalam seni tatah sungging yang dilakukan dengan cara melubangi pola pada media kulit hasil blak-blakan secara presisi dengan menggunakan perlengkapan tatah seperti ganden pemukul, berbagai macam alat tatah, landenan, dan malam pelicin. Pada tahap ini, terstimulasinya aspek motorik halus dapat dilihat selamaanak menatah berbagai bentuk pola secara presisi pada media kulit yang bertekstur keras dengan menggunakan ganden pemukul yang berat serta berbagai macam alat tatah yang berdiameter kecil, tergolong benda tajam, dan licin.Karaktersitik berbagai macam alat tatah yang berdiameter kecil, tergolong benda tajam, dan licin tersebut, mendorong jari-jemari anak lentur dan cekat dalam mengapit bagian batangnya sepanjang digunakan untuk melubangi media kulit yang bertekstur keras secara presisi.Selain itu, karakteristik bahan kulit yang memiliki tekstur keras mendorong jari-jemari, pergelangan tangan, serta lengan tangan anak luwes dalam menempatkan dan mencabut alat tatah sepanjang ujung runcingnya digunakan untuk melubangi media kulit yang bertekstur keras secara presisi. Hasil tatahan gantungan kunci, kipas, pembatas buku, hingga wayang kulit yang presisi menunjukkan bahwa melalui kegiatan ini ketepatan, kepresisian, dan ketangkasan motorik halus anak terstimulasi selama proses natah berlangsung.

Temuan di atas menunjukkan bahwa penggunaan alat dan bahan menatah yang memiliki tekstur kasar, keras, dan halus memiliki kontribusi terhadap terstimulasinya aspek motorik halus anak. Hal ini sebagaimana tercatat dalam sumber jurnal (Mironcika, Schipper, Kröse, Brons, \& Schouten, 2018) yang menyatakan bahwa penggunaan alat dan mainan yang dapat diraba bertujuan untuk melatih dan menterapi keterampilan motorik halus saat kegiatan bermain dilakukan oleh anak.

Temuan lain dari terstimulasinya aspek motorik halus anak pada tahap menatah juga dapat dilihat dari kegiatan memukulkan ganden yang memiliki beban tergolong berat tepat di atas bagian tumpul alat tatah. Karaktersitik ganden pemukul yang berat tersebut mendorong jari-jemari, pergelangan tangan, serta lengan tangan anak luwes, cekat, dan lentur dalam memukulkan bagian kepalanya tepat di atas alat tatah dengan intensitas tenaga sedang.Pukulan dengan intensitas tenaga sedang ini dilakukan anak untuk menghujamkan ujung runcing alat tatah secara presisi pada media kulit yang bertekstur keras.Hujaman presisi ini dapat dilihat dari bentuk pola tatahan yang pas dan tidak merusak media kulit yang ditatah.

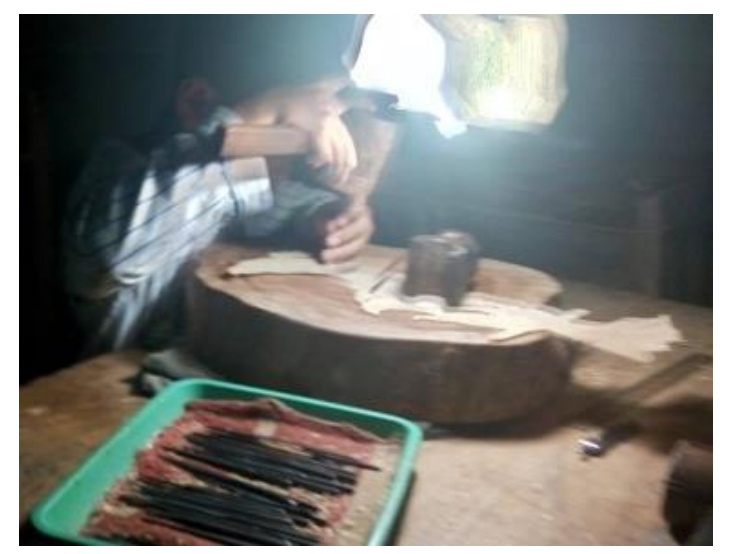

Gambar 3. Anak Menatah Wayang Kulit

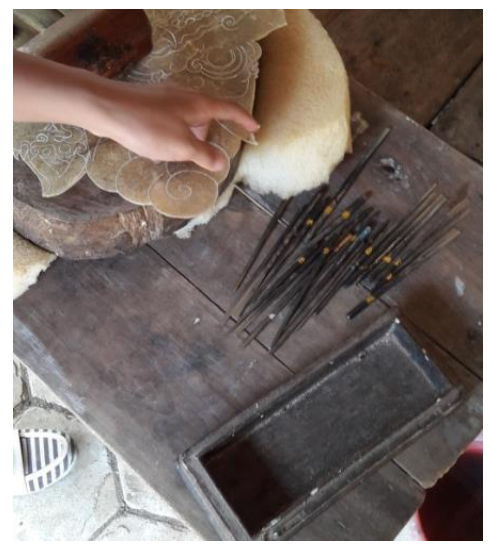

Gambar 4. Perlengkapan Menatah yang digunakan Anak 
Kegiatan menatah yang menstimulasi aspek motorik halus ini sebagaimana pandangan Kuffier melalui sumber buku (Rolina, 2012) mengungkapkan bahwa memahat merupakan salah satu dari beberapa kegiatan yang dapat mengembangkan motorik halus anak.Senada dengan pandangan di atas dalam sumber lain dijelaskan bahwa memahat merupakan salah satu kegiatan yang melibatkan koordinasi otot halus anak (Agusmiati, 2019).

Disamping itu, pada tahap ini terstimulasinya aspek motorik halus anak juga dapat dilihat selama anak mengungkal berbagai macam alat tatah menggunakan batu ungkal yang bertekstur keras dan licin.Karakteristik berbagai macam alat tatah yang berdiameter kecil, tergolong benda tajam, dan licin tersebut, mendorong jari-jemari anak lentur dan cekat dalam mengapit bagian batangnya selama ujung pipihnya menggesek tepat disepanjang cukungan batu ungkal yang keras, licin, dan berair.Selain itu, karaktersitik pengungkal yang bertekstur keras, licin, dan berair mendorong jari-jemari, pergelangan tangan, serta lengan tangan anak luwes dalam mengasahkan alat tatah selama ujung pipihnya menggesek tepat disepanjang cekungan batu ungkal. Hasil ungkalan yang memiliki ketajaman merata di bagian ujung runcing tatah, menunjukkan bahwa melalui kegiatan ini ketepatan, kepresisian, dan ketangkasan motorik halus anak terstimulasi selama proses ngungkal berlangsung.

Sebagaimana pada tahap mengeblak, pada tahap menatah juga ditemukan kegiatan yang sama yaitu mengungkal. Pada tahap mengeblak, mengungkal dilakukan dengan tujuan untuk mempertajam alat tratasan yang digunakan untuk menggores permukaan kulit mengikuti pola gambar dari karya tatah sungging yang dicontoh.Sementara itu pada tahap menatah, mengungkal dilakukan dengan tujuan utnuk mempertajam alat tatah yang digunakan untuk melubangi media kulit secara presisi.

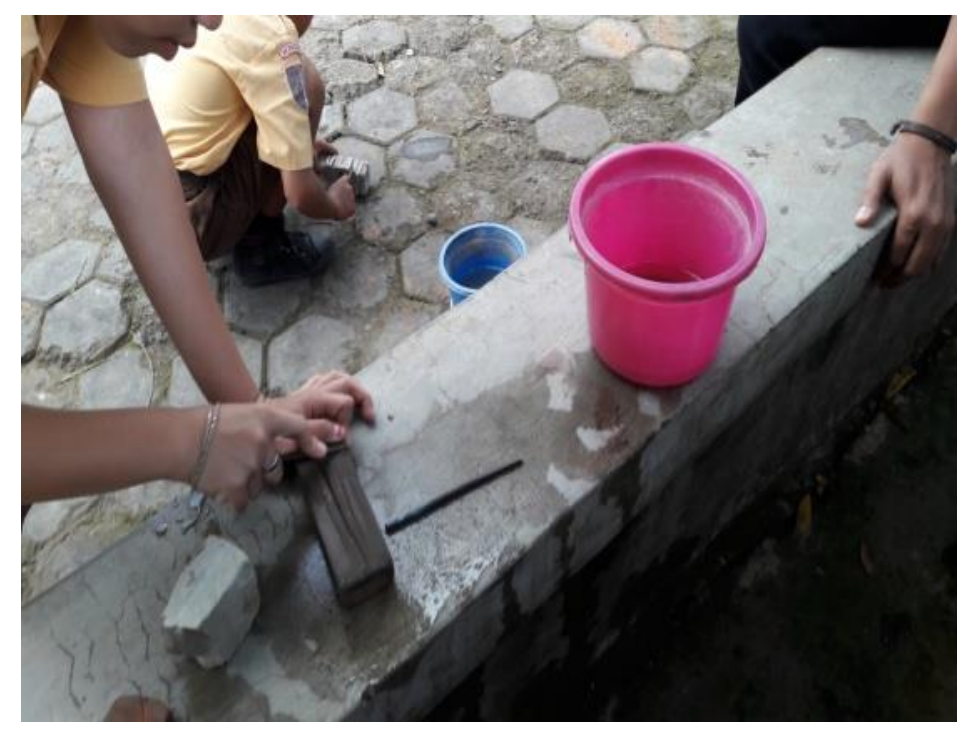

\section{Gambar 5. Anak Mengungkal berbagai macam Alat Tatah hingga Runcing agar dapat digunakan untuk Mengeblak dan Menatah}

Pada tahap menyungging, terstimulasinya aspek motorik halus anak dapat dilihat ketika melakukan teknik-teknik menyungging dengan menggunakan kuas yang berdiameter kecil. Teknik-teknik menyungging tersebut dilakukan anak secara berurutan mulai dari mulas ndasari atau memberikan warna dasar secara terarah menggunakan kuas dengan ukuran bulu besar, mulas gradasi atau memberikan pola warna bertingkat menggunakan kuas dengan ukuran bulu sedang, mulas ndrenjemi atau memberikan bulatan warna kecil menggunakan kuas dengan ukuran bulu kecil, dan nyewengi atau memberikan pola arsiran warna menggunakan pen. Teknik ini dilakukan anak dengan menggunakan kuas yang cenderung memiliki gagang kecil serta pen penyeweng yang berujung lentur.Hasil pulasan ndasari, gradasi, ndrenjemi, serta nyewengi yang presisi menunjukkan bahwa melalui 
kegiatan ini ketepatan, kepresisian, dan ketangkasan motorik halus anak terstimulasi selama melakukan teknik menyungging.

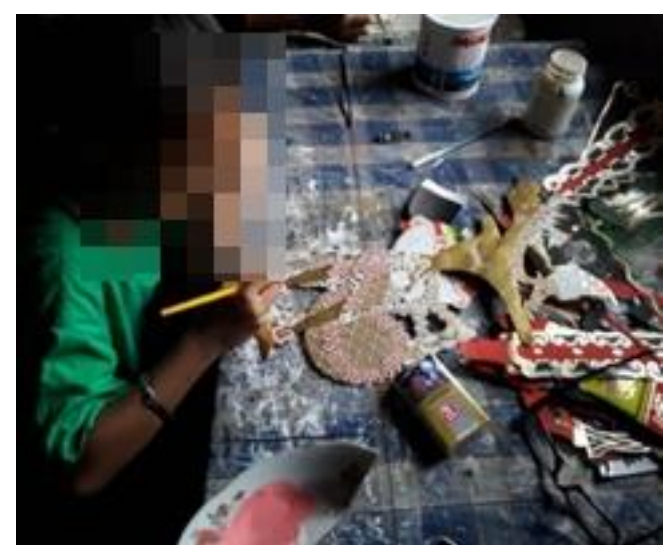

Gambar 6. Anak Menyungging Wayang Kulit

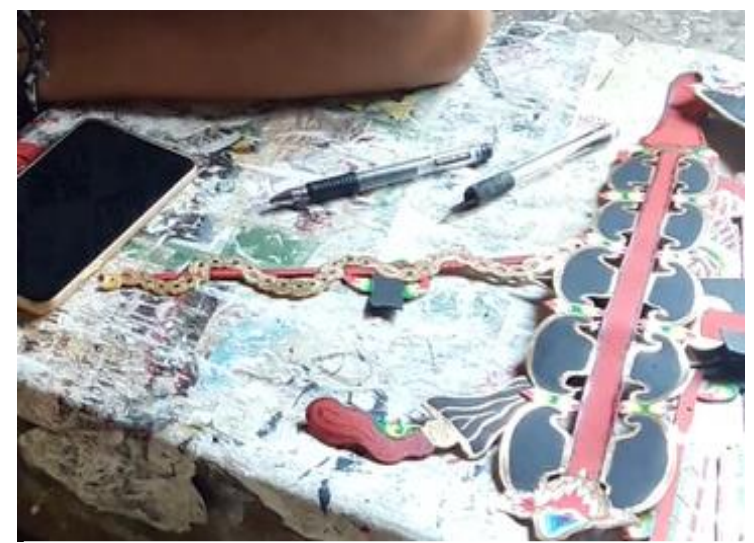

Gambar 7. Hasil Karya Sunggingan Anak dengan menggunakan berbagai macam Teknik Pulasan

Temuan di atas menunjukkan bahwa menyungging atau yang lebih dikenal dengan istilah mewarnai atau melukis dapat menstimulasi aspek motorik halus anak. Hal ini sebagaimana pandangan (Razali et al., 2019) yang menyatakan bahwa kegiatan mencampur warna menggunakan cat, jari atau tetesan air dengan sedotan membutuhkan gerakan halus yang melibatkan penggunaan otot kecil di tangan, pergelangan tangan dan jari.Sumber lain menambahkan bahwa melukis menawarkan cara tertentu yang memfasilitasi anak untuk mendapatkan pengalaman sensoris, keterampilan motorik halus, ekspresi diri, dan pencampuran warna (Atkinson, 2016). Lebih spesifik, sumber lain menjelaskan bahwa keterampilan motorik halus meliputi kemampuan anak dalam memegang krayon untuk menggambar, memegang kuas untuk melukis, dan memotong elemen buku mewarnai untuk membuat kartu ucapan (Rutkowska \& Rekowski, Witold, Bednarczuk, Grzegorz, Winnicki, Witold, Skowronski, 2018).

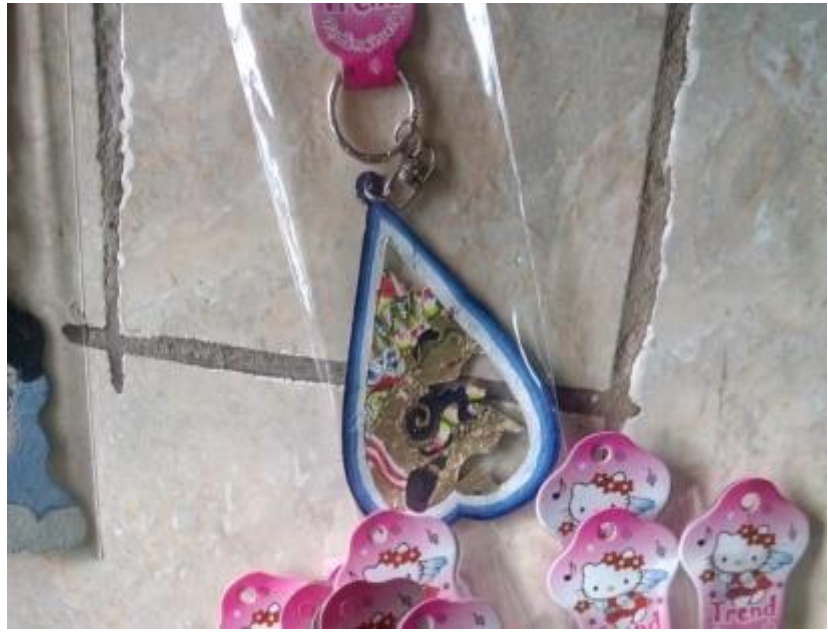

Gambar 8. Hasil Karya Gantungan Kunci Anak

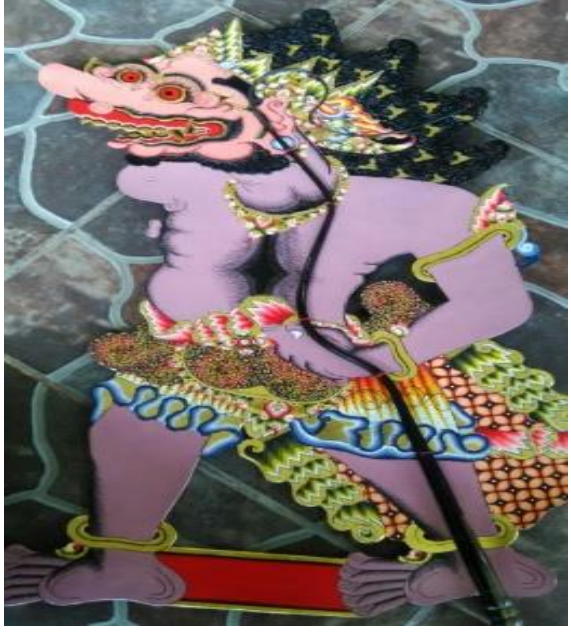

Gambar 9. Hasil Karya Gantungan Kunci Anak

Selain hal di atas, ditemukan juga bahwa terdapat beberapa proses terstimulasinya aspek motorik halus anak melalui kegiatan tatah sungging, antara lain; 1) pemberian contoh untuk mengeblak, menatah, dan menyungging menggunakan alat dan bahan tatah sungging dengan hasil yang presisi, 2) pemberian bantuan yang dilakukan oleh orang tua untuk membuat blak-blakan, tatahan, serta sunggingan kulit secara presisi dengan menggunakan 
alat dan bahan tatah sungging, dan 3) adanya arahan yang diberikan oleh orang tua pada pengeblak, penatah, serta penyungging cilik untuk menghasilkan karya presisi selama melakukan tahapan pembuatan karya tatah sungging.

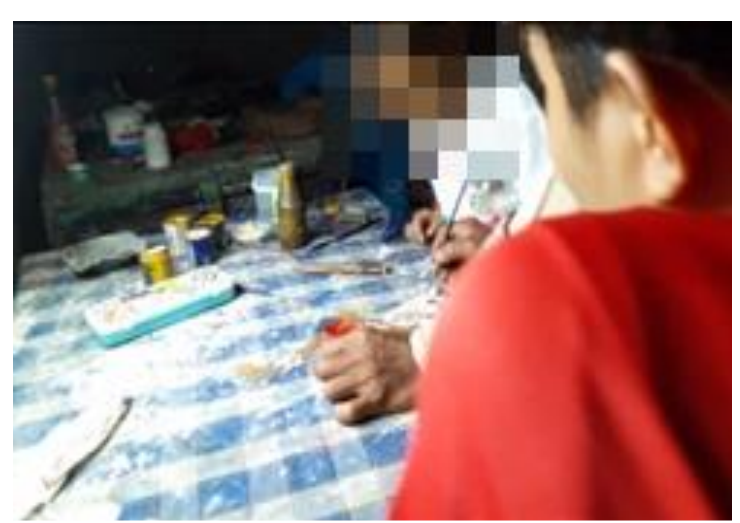

Gambar 10. Anak diberi Contoh Orang Tuanya untuk Menghasilkan Sunggingan Wayang Kulit yang Presisi

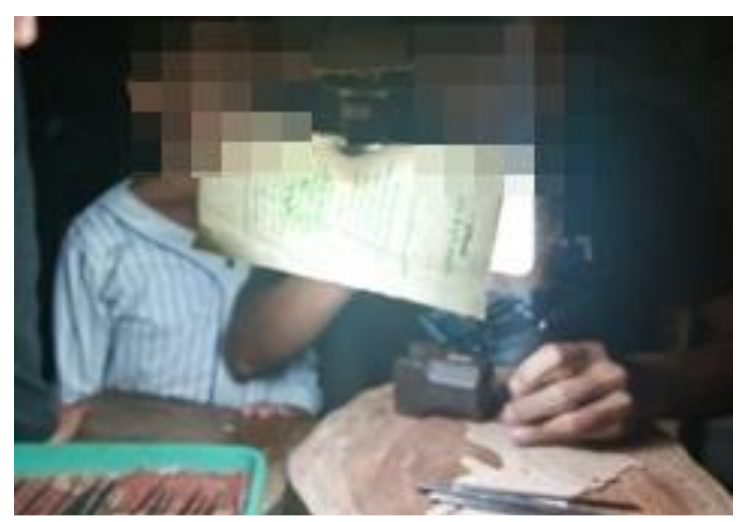

Gambar 12. Anak diberi Contoh Orang Tuanya untuk Menatah Wayang secara Presisi

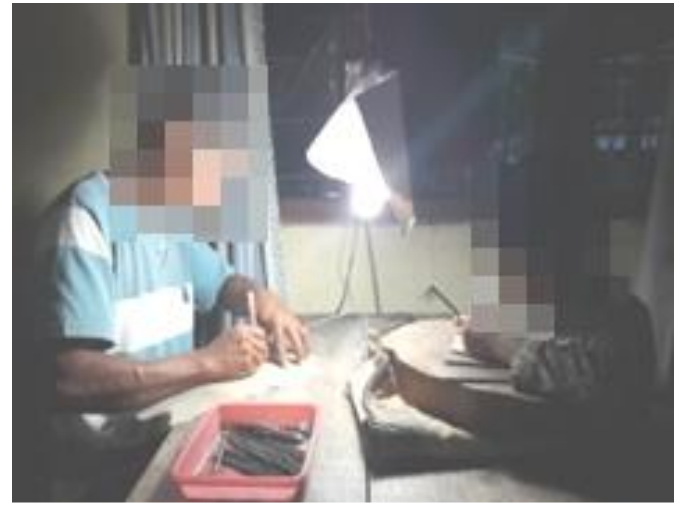

Gambar 11. Anak diberi Contoh Orang Tuanya untuk Mengeblak Gantungan Kunci secara Presisi

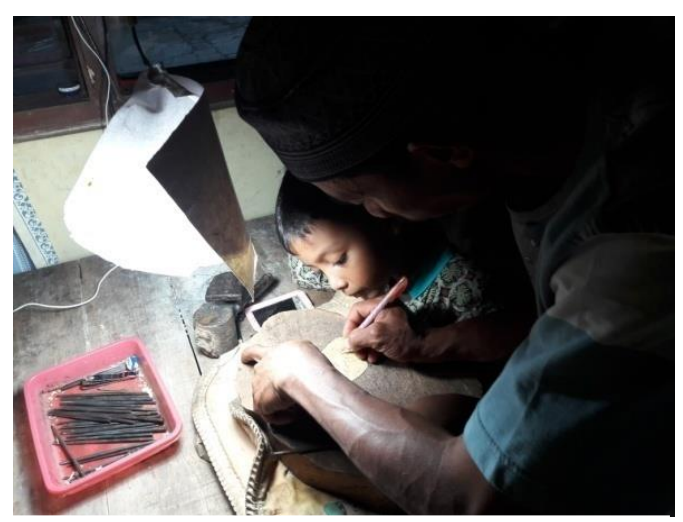

Gambar 13. Corekkan Gantungan Kunci yang akan di Tatah oleh Anak sedang dibuat oleh Orang Tuanya

Proses terstimulasinya aspek motorik halus melalui pemberian contoh dalam pembuatan karya secara presisi tersebut senada dengan hasil penelitian (Purnamasari, Negera, \& Suara, 2014) yang menyatakan bahwa kemampuan motorik halus anak TK Bdapat ditingkatkan melalui metode demonstrasi dalam kegiatan melipat kertas. Disamping itu, proses terstimulasinya aspek motorik halus melalui pemberian bantuan serta arahan orang tua untuk menghasilkan karya secara presisi tersebut juga sesuai dengan salah satu aspek utama dari teori Vygotsky mengenai "zona perkembangan proksimal" (ZPD), di mana berbagai keterampilan anak dapat dikembangkan melalui bimbingan orang dewasa atau kolaborasi teman sebaya selama terlibat dalam interaksi sosial (Fani \& Ghaemi, 2011).

Adapun, ditemukan juga bahwa terdapat beberapa faktor pendukung terstimulasinya aspek motorik halus anak melalui kegiatan tatah sungging, antara lain; 1) Adanya pujian yang diberikan oleh orang tua pada penatah, pengeblak, serta penyungging cilik yang berhasil membuat karya secara presisi, 2) Adanya hadiah yang diberikan oleh orang tua pada penatah, pengeblak, serta penyungging cilik yang berhasil membuat karya secara presisi, dan 3) adanya bentuk keteladanan orang tua yang sehari-harinya membuat karya tatah sungging secara presisi dengan menggunakan alat dan bahan tatah sungging. 


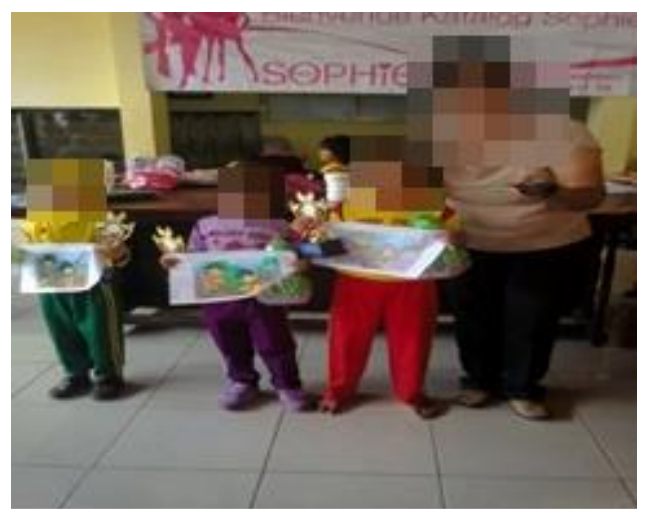

Gambar 14. Hadiah Lomba Menyungging yang diikuti oleh beberapa Perwakilan Sekolah TK di Kecamatan Manyaran

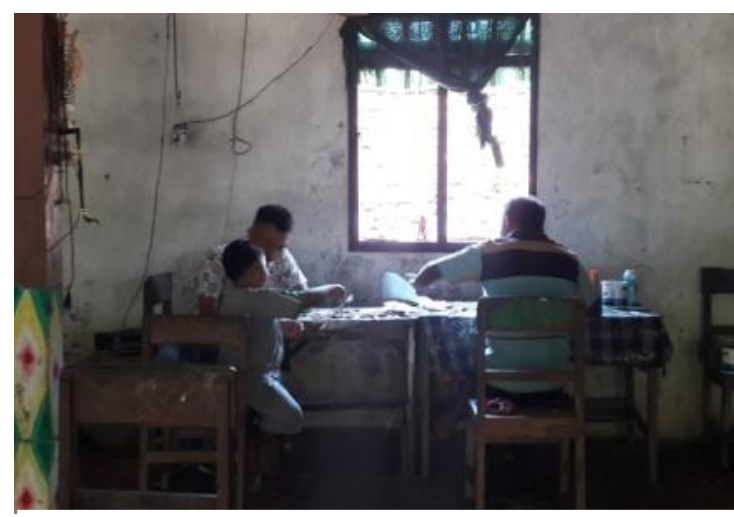

Gambar 15. Anak-anak di Kepuhsari umumnya selalu melihat rutinitas Orang

Tuanya yang sedang membuat Karya Tatah Sungging

Faktor pendukung terstimulasinya aspek motorik halus seperti pemberian pujian dan hadiah pada anak ketika dapat menghasilkan karya tatah sungging secara presisi, senada dengan prinsip penguatan positif dari teori B.F Skiner, di mana penguatan positif tersebut diberikan ketika anak dapat mematuhi kesepakatan yang telah ditetapkan bersama (Harni, 2018). Pada penelitian ini makna"mematuhi kesepakatan bersama" berkaitan dengan keberhasilan anak dalam menghasilkan karya presisi sebagaimana yang diharapkan oleh orang tuanya.Sementara itu faktor pendukung terstimulasinya aspek motorik halus berupa adanya bentuk keteladanan, senada dengan teori bandura di mana pada prinsipnya anak belajar dengan cara meniru dan mengamati apa yang ada dilingkungannya(Harni, 2018). Hal ini relevan dengan kehidupan anak-anak Kepuhsari yang sehari-harinya melihat dan meniru rutinitas orang tuanya yang sehari-hari membuat karya tatah sungging seperti gantungan kunci, pembatas buku, kipas, hingga wayang kulit.

Secara sederhana temuan mengenai terstimulasinya aspek motorik halus anak melalui proses pembuatan karya tatah sungging dideskripsikan pada table di bawah ini;

Tabel 1. Tabel Temuan Penelitian Stimulasi Motorik Halus AUD dalam Seni Tradisional Tatah Sungging

\begin{tabular}{|c|c|c|c|}
\hline Stimulasi & \multicolumn{3}{|c|}{ Kegiatan tatah Sungging } \\
\hline $\begin{array}{l}\text { Motorik } \\
\text { Halus }\end{array}$ & Mengeblak & Menatah & Menyungging \\
\hline Bentuk & $\begin{array}{l}\text { Anak dapat membuat } \\
\text { sketsa gambar secara } \\
\text { presisi di atas permukaan } \\
\text { kulit menggunakan alat } \\
\text { dan bahan mengeblak }\end{array}$ & $\begin{array}{l}\text { Anak dapat membuat } \\
\text { tatahan kulit secara } \\
\text { presisi menggunakan } \\
\text { alat dan bahan menatah }\end{array}$ & $\begin{array}{l}\text { Anak dapat membuat } \\
\text { sunggingan kulit dengan } \\
\text { teknik mulas ndasari, gradasi, } \\
\text { ndrenjemi, dan nyeweng } \\
\text { secara presisi menggunakan } \\
\text { alat dan bahan menyungging }\end{array}$ \\
\hline Proses & $\begin{array}{l}\text { Anak diberikan contoh, } \\
\text { bantuan, dan arahan } \\
\text { untuk menghasilkan } \\
\text { blak-blaan secara presisi }\end{array}$ & $\begin{array}{l}\text { Anak diberikan contoh, } \\
\text { bantuan, dan arahan } \\
\text { untuk melakukan } \\
\text { proses menatah dengan } \\
\text { hasil yang presisi }\end{array}$ & $\begin{array}{l}\text { Anak diberikan contoh, } \\
\text { bantuan, dan arahan untuk } \\
\text { melakukan teknik-teknik } \\
\text { menyungging dengan hasil } \\
\text { yang presisi }\end{array}$ \\
\hline $\begin{array}{l}\text { Faktor } \\
\text { pendukung }\end{array}$ & $\begin{array}{l}\text { Anak diberikan pujian, } \\
\text { hadiah, dan keteladanan } \\
\text { untuk bekerja dan } \\
\text { membuat blak-blaan } \\
\text { secara presisi }\end{array}$ & $\begin{array}{l}\text { Anak diberikan pujian, } \\
\text { hadiah, dan keteladanan } \\
\text { untuk bekerja dan } \\
\text { membuat tatahan secara } \\
\text { presisi }\end{array}$ & $\begin{array}{l}\text { Anak diberikan pujian, hadiah, } \\
\text { dan keteladanan untuk bekerja } \\
\text { dan membuat sunggingan } \\
\text { secara presisi }\end{array}$ \\
\hline
\end{tabular}




\section{SIMPULAN}

Tatah sungging merupakan kerajinan tangan dalam membuat wayang kulit yang dapat menstimulasi aspek motorik halus anak. Terstimulasinya aspek motorik halus anak melalui kerajinan ini dapat dilihat dari hasil blak-blaan, tatahan, serta sunggingan presisi yang dibuat dengan menggunakan alat dan bahan tatah sungging. Penggunaan alat yang memiliki diameter kecil serta bahan kulit yang permukaanya kasar dan bertekstur keras, melatih keterampilan motorik halus anak sepanjang melakukan setiap tahapan dalam kerajinan ini mengikuti tata cara pakem dalam menghasilkan karya yang presisi.

\section{DAFTAR PUSTAKA}

Abessa, T. G., Worku, B. N., Kibebew, M. W., Valy, J., Lemmens, J., Thijs, H., ... Granitzer, M. (2016). Adaptation and standardization of a Western tool for assessing child development in non-Western low-income context. BMC Public Health, 16(625), 1-13. https:/ / doi.org/10.1186/s12889-016-3288-2

Agusmiati, S. (2019). Pengaruh Permainan Puzzle Magneticeria terhadap Kecerdasan Koordinasi Gerakan Tubuh dan Motorik Anak di PAUD Karya Galang Selebar Kota Bengkulu. Journal of Early Childhood Islamic Education, 3(1), 11-21. https:// doi.org/http://dx.doi.org/10.29300/alfitrah.v3i1.2280

Atkinson, K. (2016). A Touch of Paint: Transgressing Unspoken Boundaries. Journal of Childhood $\quad$ Studies, 60-65. https:// doi.org/https://doi.org/10.18357/jcs.v41i2.16100

Carlson, A. G., Rowe, E., \& Curby, T. W. (2013). Disentangling fine motor skills relations to academic achievement: The relative contributions of visual-spatial integration and visual-motor coordination. Journal of Genetic Psychology, 174(5), 5ada14-533. https:/ / doi.org/10.1080/00221325.2012.717122

Duff, S. V, \& Wolff, A. L. (2018). Fine Motor Skill Development in Children and Youth with Unilateral Cerebral Palsy. Springer, $1-14$. https:// doi.org/https://doi.org/10.1007/978-3-319-50592-3_170-1

Fani, T., \& Ghaemi, F. (2011). Implications of Vygotsky's zone of proximal development (ZPD) in teacher education: ZPTD and self-scaffolding. Procedia - Social and Behavioral Sciences, 29(Iceepsy), 1549-1554. https:/ / doi.org/10.1016/j.sbspro.2011.11.396

Farsani, N. T., Mortazavi, M., Bahrami, A., Kalantary, R., \& Bizhaem, F. K. (2017). Traditional Crafts: a Tool for Geo-education in Geotourism. Geoheritage, 9(4), 577-584. https:// doi.org/10.1007/s12371-016-0211-2

Geuze, R. H., Schaafsma, S. M., Lust, J. M., Bouma, A., Schiefenhövel, W., \& Groothuis, T. G. G. (2012). Plasticity of lateralization: Schooling predicts hand preference but not hand skill asymmetry in a non-industrial society. Neuropsychologia, 50(5), 612-620. https:// doi.org/10.1016/j.neuropsychologia.2011.12.017

Handayani Sri, Zuhairi, N. H. (2019). Upaya Peningkatan Keterampilan Motorik Halus Anak Usia Dini Di Pekon Negeri Ratu 2 Pesisir Barat Melalui Lukisan Teknik Kolase. Pengabdian Masyarakat, 1(1), 56-63.

Harni, I. T. (2018). Implementasi Teori Behaviorisme dalam Membentuk Disiplin Siswa SDN Cipinang Besar Utara 04 Petang Jatinegara Jakarta Timur. Pendidikan Dasar, 2(2), 127138. https://doi.org/https://doi.org/10.23917/ppd.v1i2.6458

Lane, H., \& Brown, T. (2015). Convergent validity of two motor skill tests used to assess school-age children. Scandinavian Journal of Occupational Therapy, 22(3), 161-172. https:// doi.org/10.3109/11038128.2014.969308

Lin, C., Meng, L., Yu, Y., Chen, C., \& Li, K. (2014). Factor analysis of the Contextual Fine Motor Questionnaire in Children. Research in Developmental Disabilities, 35(2), 512-519. https:// doi.org/10.1016/j.ridd.2013.11.007

Lucas, B. R., Doney, R., Latimer, J., Watkins, R. E., Tsang, T. W., Hawkes, G., ... Elliott, E. J. (2016). Impairment of motor skills in children with fetal alcohol spectrum disorders in 
remote Australia: The Lililwan Project. Drug and Alcohol Review, 35(6), 719-727. https://doi.org/10.1111/dar.12375

Marsudi. (2013). Produk kulit tatah sungging I (Direktorat Pembinaan SMK, Ed.). Jakarta.

Mironcika, S., Schipper, A. De, Kröse, B., Brons, A., \& Schouten, B. (2018). Smart Toys Design Opportunities for Measuring Children's Fine Motor Skills Development. ACM, 349356. https:/ / doi.org/https:/ / doi.org/10.1145/3173225.3173256

Prayoga, D. S. (2017). Pengembangan Seni Tatah Sungging Wayang KulitMelalui Media Animasi Dua DimensiPada Sekolah Menengah Kejuruan. Seminar Nasional Seni Dan Desain, 444-447.

Purnamasari, N. K. N., Negera, I. G. A. O., \& Suara, I. M. (2014). Penerapan Metode Demonstrasi Melalui Kegiatan Melipat Kertas ( Origami ) Untuk Meningkatkan Perkembangan Motorik Halus Anak. E-Journal PG-PAUD Universitas Pendidikan Ganesa, 2(1), 1-10. https:// doi.org/http://dx.doi.org/10.23887/ paud.v2i1.3165

Putri, D. K., \& Raharjo, T. J. (2020). Area group Learning Strategies by Using Brush Away Technique in Identifying Fine Motor and Art Skills for Kindergarden. 9(3), 299-306.

Rasyid, M. (2018). Pengembangan media pembelajaran motif tatah sungging wayang kulit gaya Yogyakarta. Universitas Negeri Yogyakarta.

Razali, F. M., Aziz, N. A. A., Rasli, R. M., Zulkefly, N. F., \& Azmi, N. H. (2019). The Comparison between Fine Motor Skills Traditional Activities with Multi-Touch Gestures Screen Design: Expert Reviews. International Journal of Academic Research in Business and Social Sciences, 9(14), 1-13. https://doi.org/10.6007/IJARBSS/v9$\mathrm{i} 14 / 6503$

Rolina, N. (2012). Alat Permainan Edukatif. Yogyakarta: Ombak.

Rutkowska, I., \& Rekowski, Witold, Bednarczuk, Grzegorz, Winnicki, Witold, Skowronski, W. (2018). Analisis of Correlations Between Gross and Fine Motor Skills, Physical Fitness, and the Level of Functioning in School Children with Intellectual Disabilities. Pol. J. Sport Tourism, 25, 16-22. https://doi.org/10.2478/ pjst-2018-0003

Santoso, A. I. (2015). Potensi UMKM wayang kulit di Desa Sonorejo Kecamatan Sukoharjo Kabupaten Sukoharjo. Universitas Negeri Surakarta.

Sugiyono. (2014). Metode Penelitian Pendidikan Kuantitatif, Kualitatif, dan $R \mathcal{E} D$. Bandung: Alfabeta.

Susanto, A. (2011). Perkembangan Anak Usia Dini. Jakarta: Kencana Prenada Media.

Syafril, S., Susanti, R., Fiah, R. El, Yaumas, E., Rahayu, T., Ishak, N. M., ... Yaumas, N. E. (2018). Four Ways of Fine Motor Skills Development in Early Childhood. (i), 1-2. https://doi.org/10.31227/osf.io/pxfkq.

Tanto, O. D. (2019). Penanaman Karakter Anak Usia Dini dalam Kesenian Tradisional Tatah Sungging. Universitas Negeri Jakarta.

Tanto, O. D., Hapidin, H., \& Supena, A. (2019a). Keterampilan Sosial Pengrajin Tatah Sungging Cilik Kepuhsari. Proceedings of the ICECRS, 2(1), 83. https://doi.org/10.21070/ picecrs.v2i1.2405

Tanto, O. D., Hapidin, H., \& Supena, A. (2019b). Penanaman Karakter Anak Usia Dini dalam Kesenian Tradisional Tatah Sungging. Jurnal Obsesi : Jurnal Pendidikan Anak Usia Dini, 3(2), 337. https://doi.org/10.31004/obsesi.v3i2.192

Tanto, O., \& Kristanto, A. (2015). Pengaruh Permainan Futsal Modifikasi Terhadap Perkembangan Motorik Kasar Pada Anak Usia 4-5 Tahun. PAUD Teratai, 4(2).

Ting Liu, Michelle Hamilton, \& S. S. (2015). Motor Proficiency of the Head Start and Typically Developing Children on MABC-2. Journal of Child and Adolescent Behavior, 03(02), 1-4. https:// doi.org/10.4172/2375-4494.1000198

Wei, X. (2016). Research on the Boost of Development on Young Children ' s Fine Motor by Folk Games. Canadian Center of Science and Education, 9(9), 111-119. https://doi.org/10.5539/ies.v9n9p111 